University of Michigan Law School

University of Michigan Law School Scholarship Repository

1912

\title{
The Law in the United States in Its Relation to Religion
}

Edwin C. Goddard

University of Michigan Law School

Available at: https://repository.law.umich.edu/other/61

Follow this and additional works at: https://repository.law.umich.edu/other

Part of the First Amendment Commons, Legal History Commons, Religion Law Commons, and the State and Local Government Law Commons

\section{Recommended Citation}

Goddard, Edwin C. "The Law in the United States in Its Relation to Religion." Mich. L. Rev. 10 (1912):

161-77.

This Speech is brought to you for free and open access by the Faculty Scholarship at University of Michigan Law School Scholarship Repository. It has been accepted for inclusion in Other Publications by an authorized administrator of University of Michigan Law School Scholarship Repository. For more information, please contact mlaw.repository@umich.edu. 


\section{MICHIGAN}

\section{LAW REVIEW}

Vor. X.

JANUARY, Ig12

No. 3

\section{THE LAW IN THE UNITED STATES IN ITS RELATION TO RELIGION.*}

M.AN is a religious being. To him, everywhere and always, religion and religious institutions have been and will be of prime concern. He is also a social being. As such he has always found it necessary to live in an organized society, under some form of government. Man never has lived to himself alone. Government is not an invention, a necessary evil, to which men submit. On the contrary, from the most primitive beginnings it has been man's natural though imperfect instrument for controlling and developing the social estate so essential to his very existence. And universally this government has been more or less closely related to religious institutions.

With primitive man his government, however crude, was not more solicitous for his welfare than for that of his gods. It could not be otherwise, so long as each tribe and nation had its tribal and national deities, whose fortunes were one with those of the people of that tribe or nation, who fought for, worked for and provided for that people, but not for any other tribe or nation; who triumphed with the success, and were defeated and overthrown with the failure, in battle of the people whose gods they were. In the heathen world the state embraced as its chief department, the institutions and provisions for worship, for protecting and propagating religion. It can scarcely be said that there existed, as a separate entity, the Church; a state included church and state, unseparated and inseparable.

In the Israelitish theocracy the relation of religion and government reached its extreme expression. The Church included the

- The first of the Carew Irectures, given in Eartford Theological Seminary, Hartford, Conn., April IgII. 
state. Israel might in great crises have men as leaders but they were servants under the direct orders of Jehovah. It was Jehovah who led his people, and commanded them in war and in peace, in matters civil and religious. The laws were of his giving by direct writing upon tablets of stone. And the same code in which he issued his command against the worship of any other god, or the pursuit of labor on his Sabbath day, contained also the laws forbidding adultery and murder. When, by their demands for a king, the people at last made him so wroth that he determined to punish them by granting their request, it was Jehovah and not the people, who selected Saul and David, and the king was Jehovah's servant, his viceroy on earth in matters temporal; to whom he continually sent his commands by the word of his prophets.

It was not until the coming of the Great Teacher that we find anywhere an expression of the idea that church and state could have separate existence. Christ's "Render unto Caesar the things which are Caesar's and unto God the things which are God's," came centuries before anyone could even understand what it meant. When it was uttered, it was unintelligible alike to the Jews, who hated the Roman governors, to the Herodians, who prospered because they had accepted the Roman rule, to the disciples of Christ, who so often suffered persecution and death because the state undertook to regulate the religion of the individual, and to their successors for a millennium and a half. His declaration that his kingdom was not of this world nobody then understood, and to many it is still visionary. If we except the neutrality toward religion, of the government of Constantine who, without being conscious of what he was doing, seems to have approximated a separation of church and state, until about the time that America began to be settled we find no thought of such a separation. And yet, as we shall see, it was more than two centuries before it came to its full fruit even in this country.

From the day of Constantine onward the Holy Roman Empire and the Holy Roman Church were either in alliance, or in struggle for supremacy, but never did it occur to either state or church that they could ever be separated and independent. The only difference was that one desired the church to be supreme, the other the state. It might have been supposed that the terrible struggle, resulting in the Reformation, would have suggested to the persecuted Protestants a church whose freedom could not be interfered with by a tyrannical state. But the Protestant, no more than the Catholic, seems to have thought of such a thing. On the contrary, it is doubtless true that at that day any church upon the Continent without a strong secular sword to guard it, would have had small chance of survival. And 
in England, King Henry VIIr. had no quarrel with his double position as equally king and defender of the Faith, but only with the Pope's inconvenient refusal to aid him in his plans. When Henry took the step which made England.Protestant, he simply substituted for the Pope, himself as head of the church, and church and state continued in the same united relation as before. After some struggle under Edward VI, and counter-struggle under Mary, Elizabeth finally fixed the status of church and state that exists in England today, except for a dis-establishment under Mr Gladstone of the Protestant church in Catholic Ireland.

It will be remembered that Elizabeth had no sooner settled conditions in matters religious, than James and Charles created a ferment in both church and state. It may be supposed that the idea of separation of church and state grew out of the revolts in England of the Puritan and the Presbyterian against the established church, which were, in part, responsible for the downfall of Charles $I$, and of his pretense to the headship of church and state by divine right. But this is. scarcely the case. The Puritan did not desire a church separate from the state, but a purified church supported by a purified. state, and' when, because he could not secure in England the thing he desired, he finally came to America, his first concern was to establish a state church, in no essential respect different from the state church against which he had protested, except that this was his church. Sometimes there was a spirit of toleration, as in the case of the Pilgrims at Plymouth and the Puritans under Hooker in Connecticut, but usually the Puritan desired to use relentlessly the full power of the state in favor of his church, just as it had been used in England by the Establishment against the church for which he stood. That he could rely upon true religion to secure and hold its place by the voluntary support of its individual believers, at first did not occur to the Puritan, and when it was suggested by Roger Williams and the Quakers, he resisted it with all his might, even to the point of persecution, exile and death to the disturbers. Though there were no persecutions by the Pilgrim Fathers or the Connecticut Puritans, still even in these settlements all, whether members of the church or not, were compelled to support the state church. In the agreement between the Pilgrim Fathers and the Virginia Company, the supremacy of the state church was acknowledged, possibly because only on those terms could the king's consent be secured, and in 1650 , in Plymouth, it was forbidden to set up any church or public meetings, diverse from those already set up, without the consent and approbation of the governor. In I65I a penalty of ten shillings was provided for any neglect of church attendance, 
and in 1657 taxes were levied to support public worship. It is doubtful if in a single one of the colonies, before the Revolution, there was absolute freedom of belief and worship. Even in Rhode Island there is evidence of a restriction upon Papists, not due, of course, to Roger Williams. It is fair to say that the authenticity of this has been doubted by some. Thus, in every one of the American colonies the state already endeavored to interfere in matters religious, and in most of them a state church was established. It is an interesting and singular fact that the Baptist Roger Williams in Rhode Island, the Catholic Calvert in Maryland and the Quaker William Penn in Pennsylvania, urgently desired to give in these colonies the fullest possible freedom. But the latter two certainly were not, by the government at home, permitted to have their way.

In Massachusetts and several other colonies only church members were freemen, and in consequence, in course of time, only one in five could vote, though all were taxed for the support of the church. And even this one-fifth, if we may believe the bitter complaints of the times, contained many a man, in pew and pulpit as well, who became a member of the church merely because it was only by that means that he could exercise his rights as a citizen. Thus did the church, by seeking the support of the state, eat out its own vitals and kill in its members the spirit of true religion. In New York the Dutch Reformed: and later the Church of Eingland, and in Virginia and the Carolinas the Church of England, were the established churches, and in all the colonies some privileges or restrictions, causing constant friction and serious trouble, evidenced the interference of the state in the church and in matters of conscience.

After the Revolution, when the Constitutional Convention met to formulate an instrument that should serve as a basis of the organic law of the new union, all seemed to recognize that there could be no state church. Whence so suddenly came this idea which apparently had never before even occurred to nation builders? And how did it so readily obtain the assent of those who had been accustomed in their colonial life to the old idea? One cause, no doubt, was a practical one. If they were to establish a state church, which should it be? the Congregational of New England, the Dutch Reformed of New York and New Jersey, the Episcopalian of Virginia and the Carolinas, the Quaker of Pennisylvania, the Catholic of Maryland? Some of these were already in a minority in their own states. And the Presbyterians and Baptists and others would be ready to contend for their claims in the matter. Clearly no one church could be the church of the central government. Furthermore, many of the members of the convention, and especially followers of Mr. Jeffer- 
son, who was not himself a member, were vigorously opposed to making the central government strong, and they, no doubt, may have been most unwilling to add to its powers any control in religious matters. But making due allowance for all this, it is not believed that in any other country, or at any previous time, it would have occurred to a body of men on similar business that the way to solve the difficulty was to leave out the church, and to provide that the government should not concern itself with religious matters, leaving religion and the church to the voluntary support of believers.

The idea was not entirely new. As early as I5II the Anabaptists had put forth as part of their confession of faith the doctrine that "The magistrate is not to meddle with religion or matters of conscience, nor to compel men to this or that form of religion, because Christ is the king and law-giver of the church and conscience." A little later, from their prison, the English Separatist Browne and his followers sent over to Holland, to be printed, tracts, which they smuggled out of their prison, and these were sent back to be circulated in England. "There is no power," said they, "given the Prince to restrain any jot of liberty of the church or withhold any one person from doing the whole will of God in his calling. Much less is there any power given the Prince to try to compel the church or any member thereof to the least transgression or error." These Anabaptists and Separatists are not to be confused with the Puritans, who desired to maintain the state church, but to secure its purification. Their doctrine was that the church should consist of the regenerate only, and its membership should be voluntary, and depend upon the work of grace in the heart. Browne, who in 1582 was the first man to announce this doctrine in England, was finally harried until he gave it up. For circulating it, Coppin and Thacker were hanged at Bury St. Edmunds in June, I583. Later, John Locke, although in his model constitution for the Carolinas he had provided for the established church, reachedi a more advanced position. "The boundaries," he said, "on both sides are fixed and immovable. He jumbles both heaven and earth together, the things most remote and opposite, who mixes these societies (church and state) which are in their origin, end, business, and in everything, perfectly distinct and infinitely different."

But it is to Roger Williams that the honor belongs, not only of being the first to announce, but likewise the first to establish, in $I 6_{3} 8$, a community which recognized that no civil authority had a right to interfere in matters of religion. "An enforced uniformity of religion throughout a nation or civil state confounds the civil and religious, denies the principles of Christianity and civility, and that Jesus 
Christ is come in the flesh." But the idea did not thrive, and down to the time of the adoption of the Federal Constitution, Rhode Island still remained the only colony which did not in some manner interfere with church affairs. And yet, in every colony were men who had seen and sorely felt the evils of church control by the state, and to them it must have seemed clear how infinitely the difficulties would be multiplied if the Federal Government undertook to interfere in the establishment of any form of religion. At all events, upon the proposition of Charles Pinckney of South Carolina, Sec. 3 of Article VI of the Constitution, which provided for the oath to be taken by officers to support the Constitution, closed with that famous clause: "But no religious test shall ever be required as a qualifcation to any office or public trust under the United States." On this section North Carolina, only, voted no and Maryland was divided. "The framers of the Federal Constitution," says Schaff, in his Church and State in the United States, "remembering the persecution of dissenters and non-conformists in the mother country and in several of the American colonies, cut the poisonous tree of persecution by the root, and substituted: for specific religious tests a simple oath or solemn affirmation.

It has often been suggested that this provision of the Constitution grew out of the influence of French atheism, especially upon Franklin and Jefferson, and through them upon the whole Constitutional Convention. But Jefferson was not a member of that convention, being in Europe as Ambassador to France at that time. Every one of its members was a believer in God, and in future reward and punishment, and most of them, including the presiding officer, Washington, were church members. Of all its members Franklin has been regarded as least orthodox. And yet, during its deliberations, when it seemed impossible to harmonize the varying opinions, Franklin offered his celebrated resolution, in which he moved that "Henceforth prayers imploring the assistance of heaven and its blessings upon our deliberations be held in this assembly every morning before we proceed to business, and that one or more of the clergy of the city be requested to officiate in that service."1

1 Dr. Franklin's speech in support of this motion, as given by Madison in his papers, is worth giving in full.

"Mr. President: The small progress we have made after four or five weeks' close attendance and continual reasoning with each other-our different sentiments on almost every question. several of the last producing as many noes as ayes-is, methinks, a melancholy proof of the imperfection of the human understanding. We, indeed, seem to feel our own want of political wisdom, since we have been running about in search of it. We have gone back to ancient history for models of government, and examined the different forms of those Republics, which, having been formed with the seeds of their 
The Federal Constitution is not irreligious, it is simply nonreligious. It treats religion as individual and voluntary, and never to be forced. That church which leans upon the state for support can never be a free church. And in a state where all are required to conform in religious matters there can never be free religion.

But the adoption of Article VI, Section 3, by the Constitutional Convention was only a step. The Constitution had now to be adopted by states, and a vigorous agitation arose, by some against going so far, by others in favor of going still farther. In the Massachusetts convention two soldiers, a major and a colonel, protested against banishing the religious tests, while three ministers urged that religion was ever a matter between God and the individual, and therefore no imposition of religious tests can be made without invading the essential prerogatives of our Lord Jesus Christ. This latter view, after a struggle, finally prevailed in Massachusetts. In Virginia, on the other hand, where the state constitution had already decreed disestablishment, a more explicit guarantee against the establishment of religion was demanded. In this, the conventions of New York, North Carolina, Rhode Island, New Hampshire and a vigorous minority of Pennsylvania followed. So did the first Congress of the United States. To James Madison, among individuals, belongs the honor of being the chief advocate of a farther enactment. This agitation was 'finally successful, and Amendment $I$ of the Constitution became the first of the so-called Bill of Rights constituting the first ten amendments, adopted by the states really as a

own dissolution, no longer exist. And we have viewed modern states all 'round Elurope, but find none of their constitutions suitable to our circumstances.

"In this situation of this assembly, as it were, in the dark, to find political truth, scarce able to distinguish it when presented to us, how has it happened, sir, that we have not hitherto once thought of humbly applying to the Father of lights to- illumine our understanding? In the beginning of the contest with Great Britain, when we were sensible of danger, we had daily prayer in this room for divine protection. Our prayers, sir, were heard, and they were graciously answered. All of us who were engaged in the struggle must have observed frequent instances of the superintending Providence in our favor. To that kind Providence we owe this happy opportunity of consulting in peace on the means of establishing our future national felicity. And have we now forgotten that powerful Friend? Or do we imagine that we no longer need his assistance?

"I have lived, sir, a long time, and, the longer I live, the more convincing proofs I see of this truth-that God governs in the affairs of men. And if a sparrow cannot fall to the ground without his notice, is it possible that an empire can rise without his aid? We have been assured, sir, in the sacred writings that "except the Iord build the house, they labor in vain that build it.' I firmly believe this; and I also believe that, without his concurring aid, we shall succeed, in this political building, no better than the builders of Babel. We shall be divided by our little, partial, local interests; our projects will be confounded; and we ourselves shall become a reproach and a byword down to future ages. And what is worse, mankind may, hereafter, from this unfortunate instance, despair of establishing governments by human wisdom, and leave it to chance, war, and conquest." 
part of the original Constitution. "Congress shall make no law respecting the establishment of religion, or prohibiting the free exercise thereof." Here was a declaration broad and comprehensive, and yet clear and specific. Congress could never compel the establishment or support of the church, nor, on the other hand, could it interfere with the utmost freedom, in religious matters, of the individual. But the prohibition rests upon Congress only. Each state of the Union is still at liberty to do as it will. At the very date of the adoption of this constitution ten of the thirteen states had legal provisions respecting religion. New York and Virginia alone, at that time joined Rhode Island in complete disestablishment. In Connecticut the connection between church and state did not cease until I8I8, while in Massachusetts it was not until I833, after the members of many a Congregational church had seen the voters of the town, who outnumbered the church members, take from the inajority who attended the services their church property and turn it over to the Unitarians, that the sentiment became strong enough to procure the complete abolition of public taxation for church sup port.

We have noticed the provisions in the Federal Constitution touch. ing the relation between church and state. What, at the present time, is the situation in the varrious States? Almost every State constitution, in the preamble, refers to God, and most of them include the phrase, "Grateful to Almighty God." And yet in every State Constitution provides for a full religious liberty. Michigan was not less religious for its omission in the preamble of the name of $\mathrm{God}^{2}$, nor is New Hampshire more so for still permitting the legislature to authorize towns and parishes to provide for the support of Protestant religious teachers, a thing which, I presume, the legislature does not, and never again will, do. The requirement in Arkansas, Mississippi, Texas and the Carolinas that office holders must not deny the being of Almighty God, and of Pennsylvania and Tennessee that they must believe in God and the future state of reward and punishment, have done no more for the cause of religion than the provisions in Delaware, Kentucky, Maryland and Texas excluding the clergy from civil offices and the legislatures, have militated against it. As typical of the provisions touching religion, in our State constitutions I may quote two, one representing a positive, and the other a negative statement of the attitude of the state toward religion. The Connecticut constitution, Article VII,

2 The Revised Constitution of 1908 has supplied this omission. The phrase now occurs in the preamble of forty-five state, constitutions. 
Section I, says: "It being the duty of all men to worship the Supreme Being, the great Creator and Preserver of the Universe, and their right to render that worship in the mode most consistent with the dictates of their conscience, no person shall by law be compelled to join or support, or be classed with or associated to, any congregation, church or religious association.". The Michigan constitution of I850, Article IV, Section 39, provides: "The legislature shall pass no law to prevent any person from worshiping almighty God according to the dictates of his own conscience."3 Summarizing the effect of all the State constitutions, Judge CooLE $Y^{4}$ enumerates. five matters which are unlawful in every state:

I. Any law respecting an establishment of religion.

2. Compulsory support, by taxation or otherwise, of religion.

3. Compulsory attendance upon religious. worship.

4. Restraints upon the free exercise of religion according to the dictates of conscience.

5. Restraints upon the expression of religious belief.

Such being in general the nature of the constitutional provisions concerning religion, are we to conclude that in this country the law assumes an attitude of indifference to religion, and that, toward the church, the state maintains an attitude of complete neutrality? "Certain things, of absolute necessity to civilized society, the state is precluded from preventing. And they are left wholly to the fostering care of personal enterprise and private liberality. We concede, for instance, that religion is essential, and that without it we should degenerate to bárbarism and brutality; and yet we prohibit the state from burdening the citizen with its support and we content ourselves with recognizing and protecting its observance on secular grounds." There is the kernel of the distinction. The state may not burden the citizen with the support of religion, but it may and does, on secular grounds, recognize and protect its voluntary observance by the citizens. In the famous Ordinance of 1787 this fual attitude of state toward church is observed, and' no part of that Ordinance has been so generally noted and approved as this: Religion, morality and knowledge are necessary to good government and the happiness of mankind. Though religion is first to be mentioned, it is schools and the means of education, and not churches and the means of developing religion and morality, which the government itself forever encourages. The state will build schools, but will merely protect private individuals in building churches. Only thus,

3 The Revised Constitution of 1908, Act II, Sec. 3, retains and enlarges this provision.

- Cooley's Constitutional Limitations, p. 469 .

- People v. Salem, 20 Mich. 483. 
history teaches us, can true religion flourish, and tyranny, masking in its name, be avoided.

More specifically then, what, in this country, is the attitude of the state toward religion and morality? It has been said that in many of its laws, the state recognizes religion and passes religious enactments, for example, that half of the ten commandments have been put upon the statute books. It is true that the civil law forbids false swearing, theft, adultery and murder quite as unequivocally as did the Mosaic Law, but these provisions of the civil law do not, at least primarily, rest upon religious grounds. They are, and must be, fundamental laws in every body politic. There are many enactments as to Sunday observance, but they grow mainly out of social and economic conditions rather than out of religious requirements. To an extent, however, there is a recognition by the law of religion and religious worship, and properly so, for the Constitution guarantees to all, not merely that there shall be no compulsion to worship, but also that there shall be perfect freedom in worship, if the individual has such desires. The law and the courts, therefore, recognize the right of the worshipper to enjoy in peace and quiet his religious services, particularly upon Sunday, which is an illustration of the further fact that the laws not only have regard for religion, but for the Christian religion. In a Minnesota case ${ }^{b}$ a Jew set up that as his rest day, according to his religion, was not Sunday, therefore he could not be punished for violating the Sunday laws of the State. But the court held that this furnished no defense for his breach of the law. And in a great number of cases the courts in all the States have upheld statutes protecting the peace and quiet of the Sabbath observed by the great majority of Christians, and in many instances have not hesitated to say that these laws are upheld, not merely because it has been shown that the welfare of mankind demands for rest one day in seven, but also by reason of the fact that by the habits and customs of a great portion of the people Sunday, and not any other day, has been made the day of rest and worship.

In the same way laws against profanity, blasphemy and obscenity, and provisions forbidding the disturbance of religious meetings, are justified,partly out of respect for religion and freedom in its worship, but mainly in furtherance of good order and morals and public decency. No state can afford to be indifferent to developing good morals in its citizens, and in no country is this more clearly recognized by the courts than in our own. Furthermore, morals can hardly be divorced from religion, though the two are not identical. The

- State v. Weiss. 97 Minn. I25. 
matter has been very well stated by Jud'ge Allen of the Supreme Court of New York in the case of Lindenmuller v. People. ${ }^{\mathrm{T}}$ It is - there said among other things, that the Christian Sabbath is a civil and political institution within the just powers of the civil government, and that the prohibition of theatrical and dramatic performances on that day "rests on the same foundation as a multitude of other laws on our statute book, such as those against gambling, lotteries, keeping disorderly houses, polygamy, horse racing, profane cursing and swearing, disturbance of religious meetings, selling of intoxicating liquors on election days within a given distance from the polls, etc. All these, and many others, do to some extent restrain the citizen and deprive him of some of his natural rights; but the legislature have the right to prohibit acts injurious to the public and subversive of government, or which tend to the destruction of the morals of the people and disturb the peace and good order of society. It is -exclusively for the legislature to determine what acts should be prohibited as dangerous to the community."

Moreover there are more direct and specific ways in which the state encourages and recognizes the church and Christianity. As already noted, nearly all the States in their constitutions recognize God, and réquire of public officers an oath which recognizes God and is ordinarily taken upon the Bible. The President of the United States and the governors of the several States officially appoint Thanksgiving a day of prayer and thanksgiving to almighty God for his providence and protecting care. Thanksgiving and Christmas are everywhere legal holidays. The leaders of the nation, in their public papers, almost without exception from Washington down, have recognized the dependence of the nation upon almighty God. Thus, Washington in his first inaugural address in 1789 said: "It would be peculiarly improper to omit, in this official act, my fervent supplications to that Almighty Being who rules over the Universe, who presides in the councils of nations, and whose providential aid can supply every human defect, that His benediction may consecrate to the liberties and happiness of the people of the United States a government instituted by themseives for these essential purposes, and may enable every instrument employed in its administration to execute with success the functions allotted to his charge. In tendering this homage to the great Author of every public and private good, I assure myself that it expresses your sentiments not less than my own; nor those of my fellow citizens at large, less than either. No people can be bound to acknowledge the invisible

I 33 Barb. 560. 
hand which conducts the affairs of men more than the people of the United States $* * *$ The propitious smiles of heaven can never smile on a nation that disregards the eternal rules of order and right which heaven itself has ordained." Lincoln, in his two immortal addresses, his second inaugural and the Gettysburg address, paid sublime and tender tribute to the divine justice and 'mercy, concluding the latter address with that hope expressed in immortal words: "That this nation, under God, shall have a new birth of freedom, and that government of the people, by the people, and for the people shall not perish from the earth."

But not only has there been this recognition by word of the relations of this nation to almighty God, but the laws of the country in many ways especially favor and provide for religious work. Thus, churches and other organizations engaged in religious work, are almost universally relieved from taxation upon property devoted to religious uses, and the courts, under our constitution, justify such exemptions. Soldiers and. sailors are urged to attend divine service, and moreover public moneys are lawfully expended in the employment of chaplains for our armies, our legislative bodies, our prisons and other public institutions, and at the public expense chapels are built in which these services may be.held. In places not provided with buildings for public worship, schoolhouses are frequently granted to religious bodies, ${ }^{8}$ though the right has been disputed. And all this to the end, not that the state may bring any compulsion upon the individual in religious matters, or compel him to support any sect, but in order that religion, which is essential to the welfare of the state, and the happiness of mankind, may ever be encouraged.

In this connection the question which, more than any other growing out of the relation between church and state, has been the occasion of earnest and not infrequently of violent controversy, is that of religious teaching in the public schools. The prejudiced and excited feeling of the disputants has often resulted in much heat with little light. Although occasionally in times past the infidel, as a few years . ago anyone was likely to be called who opposed either the Bible, or $m y$ interpretation of any part of it, raised his voice in loud protest against religion of any sort in the schools, yet more often the contest was waged between the Trinitarian, who wanted to have read in the schools the whole of the King James Bible, and the Catholic, who whether he would have been satisfied with the Douay version or not, certainly was strongly opposed to the King James, the Unitarian who objected to alleged unauthentic passages as to the trinity,

- See Nichols v. School Directors, 93 IIl. 6r. 
and false teaching as to the being and work of Christ, the Jew who objected possibly to the whole of the New Testament, and some other sects who strongly opposed the use of the Bible at all. There is substantial agreement that the school is the "chief nursery of popular intelligence, virtue and piety." (Schaff.) Virtue and piety resting upon religion, the deduction is made that a Godless school cannot answer the purpose of the state in training future citizenship. Some have therefore proposed that the school funds be divided and paid over to the church of the taxpayer's preference for the support of: church schools. That, to an extent; has been done in England and Canada, but has never been done in this country, and is in most States doubtless unconstitutional. In the great majority of the schools reading of the Bible without comment, singing of hymns, repeating the Lord's Prayer and other prayers, have been permitted without opposition, on the ground that such exercises were not sectarian. In an interesting Michigan case ${ }^{0}$ the use, in schools, of a book of selections from the Bible was upheld, although a vigorous dissenting opinion was filed. The court said that the Michigan constitution was adopted under the authority conferred by the Ordinance of 1787 . That Ordinance declared that religion, morality and knowledge were necessary to good government and the happiness of mankind, and provided that for these purposes schools and the means of education should forever be encouraged. It is not to be inferred that in forming a constitution, under the authority of this ordinance, the convention intended to prohibit in public schools all mention of a subject which the ordinance in effect declared that schools are established to foster. The court went on to say that it did not wish to be understood as declaring that the Ordinance of I787 made it imperative that religion should be taught in public schools, but the facts show that from the admission of the- State, during more than half a century, the practice had been followed, in all state institutions' of learning, of reading from the Bible in the presence of students, and of offering prayer. Furthermore, the text books used in the schools contained extracts from the Bible, and numerous references to almighty God and his attributes, and no objections had been made. The court would take judicial notice of these usages. It quoted from Judge Cooley in his Constitutional Limitations, page 578 , to the effect that: "The American constitutions contain no provisions which prohibit the authorities from such solemn recognition of superintending Providence in public transactions and exercises as the general religious sentiment of man-

- Pfeiffer v. Board of Education of Detroit, I18 Mrich. 560 . 
kind inspires, and as seems meet and proper in finite and dependent beings. Whatever may be the shades of religious belief, all must acknowledge the fitness of recognizing; in important human affairs, the superintending care and control of the Great Governor of the Universe and of acknowledging with thanksgiving his boundless favors, of bowing in contrition when visited with the penalties of his broken laws. No principle of constitutional law is violated when thanksgiving or fast days are appointed; when chaplains are designated for the army and navy; when legislative sessions are opened with prayer or the reading of the Scriptures; or when religious teaching is encouraged by a general exemption of the houses of religious worship from taxation for the support of State government." The court held that the reading of these selections from the Bible without comment was not teaching of any theological doctrine, nor any interference in any way with the religious belief derived by the scholars from their parents.

In a leading case in Wisconsin, ${ }^{10}$ on the other hand, the court arrived at the opposite conclusion, holding that the reading of the Bible at stated times in a common school is sectarian instruction and an act of worship, and that for both reasons such reading of the Bible came within the prohibition of the Wisconsin constitution. It appeared that the whole Bible, and not merely selections, was in use, and the court said it would take judicial notice that the Bible contained doctrines of the divinity of Jesus Christ, as to the punishment of the wicked after death, as to predestination, as to the apostolic succession and authority of priesthood, as to the necessity and efficacy of the sacraments of the church, as to all of which matters the various sects maintain different and conflicting doctrines. The doctrines of one of these sects which are not common to all the others are sectarian in the sense in which that word is used in the constitution. The court was not concerned with the truth or error of any of these doctrines, but only to know whether such reading of the Bible was sectarian instruction. "To teach the existence of a Supreme Being of infinite wisdom, power and goodness, and that it is the highest duty of all men to adore, obey and love Him, is not sectarian, becanse all religious sects so believe and teach. The instruction becomes sectarian when it goes farther, and inculcates doctrine and dogma concerning which the religious sects are in conflict. $* * *$ That the reading from the Bible in the schools, although unaccompanied by any comment on the part of the teacher, is instruction, seems to us too clear for argument. Some of the most

${ }^{20}$ Weiss v. District Board, 76 Wis. 177. 
valuable instruction a person can receive may be derived from reading alone, without any extrinsic aid by way of comment or exposition. The question therefore seems to narrow down to this: Is the reading of the Bible in the schools-not merely selected passages therefrom, but the whole of it-sectarian instruction of the pupils? In view of the facts already mentioned, that the Bible contains numerous doctrinal passages upon some of which the peculiar creed of almost every religious sect is based, and that such passages may reasonably be understood to inculcate the doctrines predicated upon them, an affirmative answer to the question seems unavoidable. $* * *$ A most forcible demonstration of the accuracy of this statement is found in certain reports of the American Bible Society of its work in Catholic countries, in which instances are given of the conversion of several persons from Romanism through the reading of the Scriptures alone; that is to say the reading of the Protestant, or King James version, of the Bible converted Catholics to Protestants without the aid of comment or exposition. In those cases the' reading of the Bible certainly was sectarian instruction." The court went on to say, however, that this did"not banish from text books the fundamental teaching of the Bible, or extracts therefrom. Such teaching and extracts as literature for secular instruction cannot be objected to, and much of the Bible cannot be criticised as sectarian. No more complete moral code exists than is found in the New Testament. There is no objection to the use of such portions to inculcate good morals, for religious sects do not disagree upon the fundamental principles of moral ethics. The fact that children were not obliged to remain to the reading of the Bible, the court thought did not relieve the practice from objection. Religion in the sense of natural law might be taught, but as a system of belief, it cannot be taught in our common schools, which must be exclusively secular. - Let it once enter our common schools and it becomes a source of strife," quarrel, fights, malignant opposition, persecution and war. "Re ligion needs no support from the state. It is stronger and much purer without it. $* * *$ Morality and good conduct may be inculcated in the common schools and should be. The connection of church and state corrupts religion and makes the state despotic."

It is not possible to reconcile all of the decisions, and yet out of them seems to be emerging a compromise position, which will allow in the schools a place, under some guise, for the use of at least such portions of the Bible as command substantially universal assent. Thus, a recent Kentucky case took the ground that it was proper to read the Bible in public schools. If the teaching of Confucius of Mahomet might be profitably studied, why not also the wisdor. 
of Solomon and the life of Christ? The court concludes after an examination of the authorities that "The reason and weight of the authorities supports the view that the Bible is not in itself a sectarian book, and when used merely for reading in the common schools, without note or comment by teachers, is not sectarian instruction; nor does such use of the Bible make the schoolhouse a house of religious worship."11 And in a still more recent case the Supreme Court of Texas held that one or more individuals have no right "to have the courts deny the people the privileges of having their children instructed in the moral truth of the Bible, because such objectors do not desire that their own children shall be participators therein. This would be to starve the moral and spiritual needs of the many out of deference to the few."12 It is certainly to be hoped that this question may be viewed in a large way, so that, without doing violence to the conscience of any, schools may be made a means of inculcating the fundamental principles of all religions, and the precepts of morality that are so necessary to good citizenship. The matter is one of great difficulty, but might perhaps be worked out by a conference and union of people holding the various shades of opinion.

It has, in some of the States, been held that Christianity is part of our common law. We have already said enough to make it clear that in many ways our common law presupposes Christianity, but it must be clearly obvious that it is only in a very limited sense that Christianity can be said to be a part of our common law. ${ }^{13}$

I1 Hackett v. School District, 120 Ky. 608, 69 I. R. A. 592.

12 Church v. Bullock, Iog S. W. irs. But compare People v. Board of Education, 245 I11. 334.

${ }^{13} \mathrm{Mr}$. Webster, in his memorable argument in the Girard College case, 2 How. (Uं. S.) r27, based his attack upon the will of Stephen Girard largely upon this view that Christianity is part of our common law, and Mr. Girard's provision in his will that no clergyman of any sect should ever have any part in, or even be admitted to the college which he proposed to establish for the education of orphans, Mr. Webster, claimed was anti-Christian, against the common law of Pennsylvania, and that therefore the proposed trust was void. The idea was expressed in Mr. Webster's classic paragraph: "The massive cathedral of the Catholic; the Episcopalian church with its lofty spire pointing heavenward; the plain temple of the Quaker; the log church of the hardy pioneer of the wilderness; the mementos and memorials around and about us; the consecrated graveyards, their tombstones and epitaphs, their silent vaults, their mouldering contents, all attest it. The dead prove it as well as the living. The generations that are gone before speak it and pronounce it from the tomb. We feel it. All proclaim that Christianity, general, tolerant Christianity, Christianity independent of sects and parties, that Christianity to which the sword and fagot are unknown, general tolerant Christianity, is the law of the land." We may add that the law of the land is not a toleration of religion merely, for "toleration is a concession which may be withdrawn. It implies a preference for the ruling forms of faith and worship, and a practical disapproval of all other forms." As Judge Cooley has stated in his Constitutional Limitations, the American Constitutions have established not religious toleration merely, but religious equality. 
It was doubtless the common law of England; but it is not a part of the English law which we have brought over and adopted as our own. Not to Christianity alone, but to Mohamedanism, Brahmanism Confucianism as -well, liberty of religious opinion and of worship are guaranteed. Upon this one limitation must be noted. It is only opinions, that, by the constitution, are placed wholly beyond legislative control. As Chief Justice WAITE in a leading case, ${ }^{14}$ expressed it: "Congress was deprived of all legislative power over mere opinion, but was left free to reach actions which were in violation of social duties or subversive of good order." If one's religious belief leads him to indulge in polygamy, or utterly to disregard the - institution of marriage, or, denying all rights of property, to appropriate to his own use the property of others, his religious belief will not relieve him from the operation of the law, any more than would be the case if his religious belief led him in his own worship to offer human sacrifices. While a citizen may think as he will upon matters religious he must not act in a way offensive to the sacred customs and institutions of our social order. Religious liberty is not to be mistaken for religious or social, license. But the state will interfere when principles brealk out into acts against peace and good order. It is on this ground that the courts have interfered with Mormonism as soon as the Mormon church translated its belief in plural marriages into the practice of polygamy, and it is on the same ground that the state has refused to interfere with the practice of Christian Science because in nearly all cases it has appeared that the belief did not result in acts subversive of the rights of others.

Finally, we remark, that the state concerns itself with the church and its government in all cases involving civil, personal or property rights of the church organization, or its members or beneficaries. The Fiederal Constitution provides unequivocally against any action by the United States, or the several States, the effect of which is to deprive any person, natural or artificial, of his life, liberty or property without due process of law. Under this provision his church rights can be taken from him no more than his civil rights. The strong arm of the secilar courts may reach out for or against the church, just as it may for or against any other body.

UNIVERSITY OF MICHIGAN.

EDWIN C. Goddard. .

2 Reynolds $\nabla$. United States, 98 U. S. 162. 